\title{
Effect of Triphala on dental bio-film
}

\author{
L. Jagadish ${ }^{\mathrm{a}}$, V.K.Anand Kumar ${ }^{\mathrm{b}}$ and V. Kaviyarasan ${ }^{* a}$ \\ ${ }^{a}$ CAS in Botany, University of Madras, Guindy Campus, Chennai - 600025 \\ ${ }^{b}$ Ramachandra Medical College, Porur, Chennai-600 025, India. \\ jkl_phd@yahoo.co.in; manikavi53@gmail.com*
}

\begin{abstract}
The free radical scavenging property and antimicrobial activity of Triphala- the herbal product made of equal proportion of Terminalia chebula, Terminalia belerica and Emblica officinalis, were evaluated. Ethanol extracts of the formulation were tested for its total antioxidant activity using improved ABTS radical cation decolorizing assay and antibiotic assay against Streptococcus mutans (predominantly involved in bio-film formation on human teeth). An effort was also made to correlate its antiplaque activity using an in-vitro assay (conditions were kept similar to oral cavity) with Triphala and two commercial toothpastes (Product 1 and product 2). The herbal extract effectively inhibited the bio-film formation and the better antioxidant activity exhibited by the extract might protect the gum cells effectively from free radicals than the commercial toothpastes. Thus Triphala can be used as an effective antiplaque agent.
\end{abstract}

Keywords: ABTS, antiplaque, Terminalia, triphala. Introduction

Human dental plaque was one of the ecosystems in which microorganism was first observed. Dental plaque refers to the aggregates of bacterial cell embedded in a polysaccharide and protein matrix which adheres to the teeth by a characteristic bacterium, Streptococcus mutans (Scherp, 1971). This organism metabolizes sucrose in a peculiar way, producing an extracellular adhesive polysaccharide (dextran), a sticky insoluble glucan which promotes the firm adherence of the organisms to the tooth surface contribute the formation of dental plaque, subsequently leads to localized decalcification of the enamel surface (Ooshima et al., 1994).

Several anti-plaque agents are being available in the market. However, due to several undesirable side effects associated with these agents stimulated the search for alternate agents (Schee, 1989). In recent years, there has been focus on plants or plant products used in folk dental practice or presumed in Unani, homeopathic or Ayurvedic remedies (Memory, 1986). Natural compounds contained in the herbal cocktail can act in a synergetic manner within the human body, and can provide unique therapeutic properties with minimum or no undesirable side effects.

One such herbal cocktail is Triphala, the herbal product of equal proportion of dry powder of Terminalia chebula, Terminialia belerica and
Emblica officinalis being used extensively in Indian system of medicine having anti-diabetic and antioxidant activity (Sabu \& Kuttan, 2002). It has also been used as laxative in Siddha and Ayurveda medical systems. $T$. chebula which acts as anticaries agents strongly inhibits the sucrose or glucan induced aggregations of $S$. mutans (Jagtap \& Karkera, 1999) and strengthens the gums, prevents and treats several diseases of mouth such as dental caries, spongy and bleeding gums gingivitis and stomatids (Date \& Kulkarni, 1995). Hence, an attempt was made to study antioxidant and antimicrobial properties of Triphala in comparison with commercially available tooth pastes, Product 1 and Product 2.

\section{Materials and methods}

\section{Preparation of the extract}

Triphala churna, an Ayurvedic medicine used in the experiment is manufactured in India by Dabur India Limited. The commercial tooth pastes, Product 1and Product 2 were purchased from the local market. The samples were suspended in 100 $\mathrm{ml}$ ethanol and kept in shaker for 48 hours; extracts were separated using rotary vaccum evaporator. Total Antioxidant Activity

The Trolox equivalent antioxidant capacity (TEAC) of Triphala compared with commercially available tooth paste Product 1 and Product 2 was estimated using the Feryl Myoglobulin/ ABTS method for total antioxidant activity (Pellegrini et al., 1999). This technique measures the relative ability of antioxidant substance to scavenge the ABTS radical cation (ABTS ${ }^{-}$) generated in aqueous phase, compared with standard synthetic antioxidant Trolox (6-hydroxy-2-5-8 tetra methyl chroman-2-carboxilic acid) a vitamin-E analogue. Test samples prepared in different concentrations i.e., 50, 100, 150, 200 and $250 \mu \mathrm{g} / \mathrm{ml}$ were added to the tube containing $7 \mathrm{mM}$ ABTS and $140 \mathrm{mM}$ potassium per-sulphate diluted with ethanol to O.D. 0.7 at $734 \mathrm{~nm}$. The antioxidant property was determined by reduction in the O.D. compared with the standard Trolox.

Antimicrobial activity

Agar well diffusion method: The effect of ethanol extract of Triphala and commercial tooth pastes against $S$. mutans was determined by agar well diffusion method. The 18 hours old culture of $S$. mutans was incorporated in nutrient agar and poured into the Petri-plates, allowed to set. Wells 
were made using cork-borer $(8 \mathrm{~mm}$ diameter) and were loaded with extracts along with appropriate controls. The zone of inhibition obtained with various concentrations of the extracts was observed after 24 hours incubation at 37으.

Minimum inhibitory concentration (MIC): Analysis of minimum inhibitory and minimum bactericidal concentration (MIC \& MBC) was determined for $S$. mutans. The test was carried out for the ethanol extract of Triphala, Product 1 and Product 2. A two fold dilutions of the extracts were prepared and the MIC \& MBC were determined.

In vitro assay reflecting oral condition

An in-vitro assay (Evans et al., 1977) using saliva treated human teeth for determining the potential of chemotherapeutic agent's ability to adsorb, to the tooth surface and act against plaque forming bacteria was carried out. The tooth was coated by shaking in sterile saliva on a rotating platform at $150 \mathrm{rpm}$ at room temperature for one hour. The coated tooth was then rinsed twice in sterile phosphate buffer saline. The rinsed tooth was placed in small plastic Petri-dishes containing various concentrations of the test drugs (Triphala, Product 1 \& Product 2) and left for two minutes with gentle agitation, after that they were rinsed in $5 \mathrm{ml}$ phosphate buffer saline for two minutes for two times, and immersed in sterile distilled water for two minutes with a control. The rinsed tooth was placed in cotton stopper glass tube containing $1 \mathrm{ml}$ of medium. Each tube was inoculated with 50 $\mu \mathrm{l}$ of 24 hours culture of test organism ( $S$. mutans) and incubated at $37^{\circ} \mathrm{C}$ for 24 hours under aerobic conditions.

After incubation, non adherent cells were removed carefully by decanting the tube, cells adhered to the tooth surface were washed twice with $0.5 \mathrm{ml}$ phosphate buffer saline and the washing was combined with previously removed non adherent cells. The tooth was then transferred to $1 \mathrm{ml}$ of $0.1 \mathrm{~N}$ sodium hydroxide and suspended for sonification at 20 watts for 20 seconds. The optical density of the fractions, adherent and nonadherent was taken at $540 \mathrm{~nm}$. The cells adhere to the tooth will referred as plaque forming unit's responsible for plaque formation on tooth.

Results

Antioxidant property of Triphala compared with commercial tooth paste Ethanolic extracts of Triphala,
Fig. 1. In-vitro antioxidant activity of ethanolic extract of Triphala, Product 1 and Product 2, trolox equivalent (Pelligrini et al., 1999).

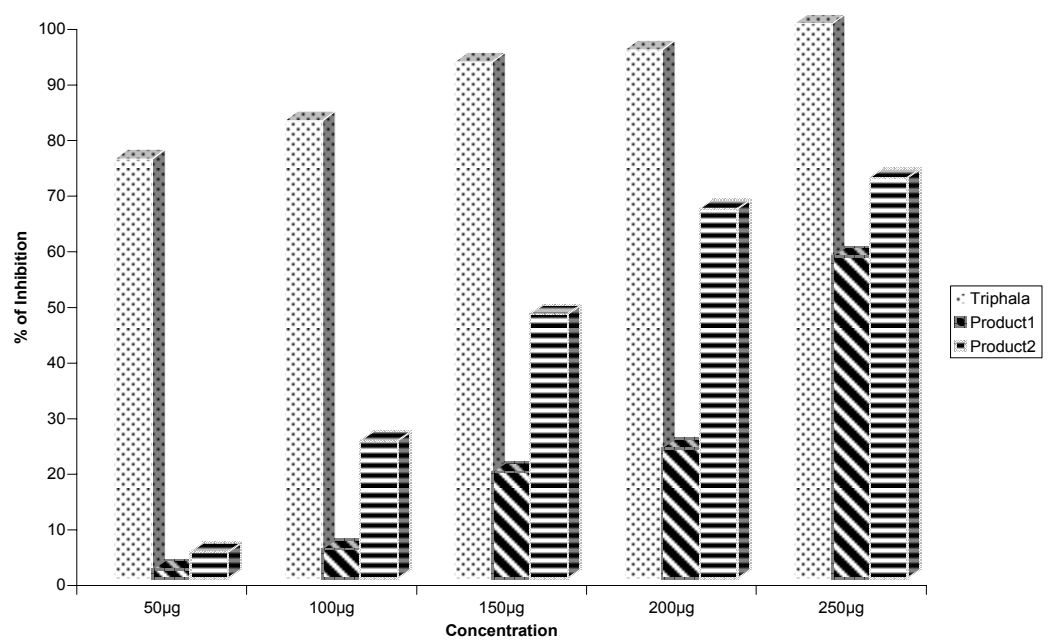


Table 2. Anti-Streptococcus activity of Triphala, Product 1 and Product 2.

\begin{tabular}{|c|c|c|c|c|c|c|}
\hline \multirow{2}{*}{ Organism } & \multirow{2}{*}{$\begin{array}{c}\text { Ethanol } \\
\text { Extract }\end{array}$} & \multicolumn{5}{|c|}{ Concentration $\mu \mathrm{g} / \mathrm{ml}$} \\
\cline { 3 - 7 } & & 800 & 400 & 200 & 100 & 50 \\
\hline S. mutans & Triphala & $\mathrm{NT}^{\mathrm{a}}$ & $\mathrm{NT}$ & $\mathrm{NT}$ & $\mathrm{NT}$ & $\mathrm{NT}$ \\
\hline S. mutans & Product 1 & NT & NT & NT & NT & $\mathrm{T}^{\mathrm{b}}$ \\
\hline S. mutans & Product 2 & NT & NT & NT & NT & T \\
\hline
\end{tabular}

${ }^{a}$ No turbidity (No growth); ${ }^{b}$ Turbid (Presence of growth)

$100 \mu \mathrm{g} / \mathrm{ml}$ against $S$. mutans (Table 2).

In-vitro assay reflecting oral condition

The assay was employed to test the effect of Triphala and commercial tooth pastes like Product 1 \& Product 2 against growth and plaque formation by $S$. mutans with concentrations of $5 \%$ and $10 \%$. Triphala effectively controlled the plaque formation by inhibiting $83.72 \%$ growth of $S$. mutans in $5 \%$ solution and $86.34 \%$ in $10 \%$; whereas the activity range for Product 1 and Product 2 was $75 \%$ in $10 \%$ solution and $35 \%$ in $5 \%$ of the solution (Fig. 2), respectively.

\section{Discussion and conclusion}

The unique aspect of the work is to confirm the importance of herbal product for its medicinal, antioxidant and antimicrobial relation. The results obtained indicate that Triphala (equal proportions of Terminalia chebula, Terminalia belerica and Emblica offficinalis) had potent antioxidant and antimicrobial activity and inhibited the growth of $S$. mutans, gram positive cocci, involved in plaque formation when it adsorbed to the tooth surface.

The strong antioxidant activity of Triphala may be partially responsible for many of the biological properties (Sabu \& Kuttan, 2002). T. belerica was

Fig. 2. Effect of Triphala, Product 1, Product 2 on the biofilm formation on human tooth under in-vitro condition (Evans et al., 1977).

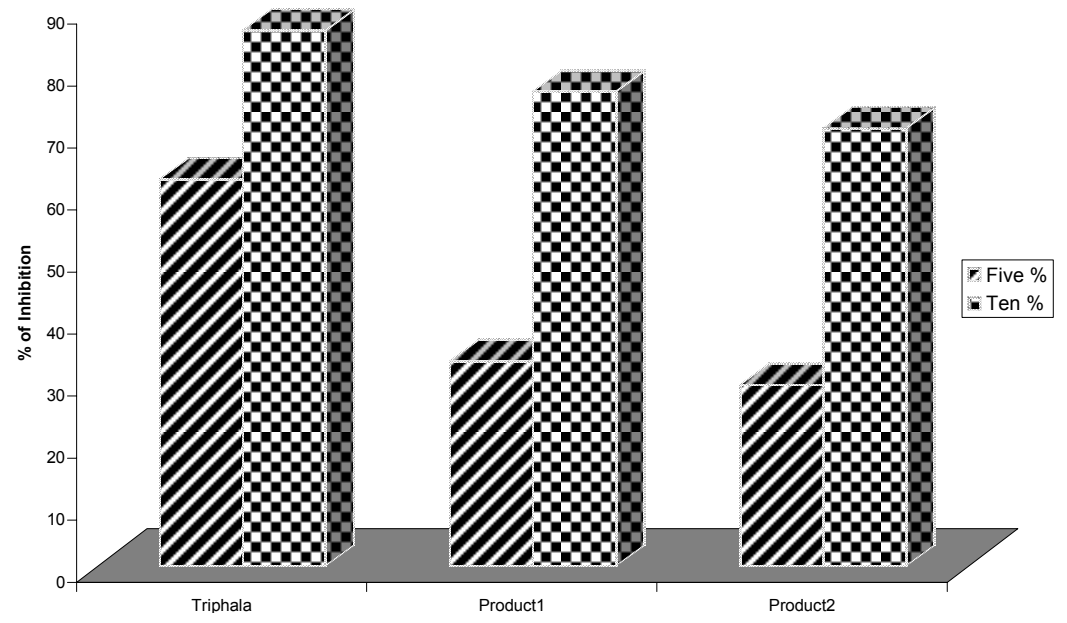

"Triphala for dental care" http://www.indjst.org Vol.2 No 1 (Jan. 2009)

the most active antioxidant followed by E. officinalis and T. chebula. The major ingredients of T.bellerica are ellagic and gallic-acid; $E$. officinalis has several gallic acid derivatives including epigallocatechin gallate and in $T$. chebula gallic acid is the major ingredient (Sabu \& Kuttan, 2002; Lee et al., 2005). The presence of these active ingredients of phenolic nature may be responsible to scavenge the free radicals generated by $\mathrm{ABTS}^{+}$in $\mathrm{a}$ solution.

Tannic acid represents the major constituent of the ripe fruit of $T$. chebula, T.belerica and E. officinalis (Chopra \& Handa, 1958). Earlier studies reported that tannic acid is bacteriostatic or bactericidal to some gram positive and gram negative pathogens (Kau, 1980). Similarly the ethanol extract of herbal powder showed antibacterial activity in minimum concentration of $50 \mu \mathrm{g} / \mathrm{ml}$ against $S$. mutans in the present study.

S. mutans adheres to the tooth surface by virtue of its glucan binding protein that leads to the formation of dental plaque. An in-vitro assay on the formation of a pellicle over the human tooth surface was performed before and after exposure to the drug. Adherent and non-adherent cells could be measured (Turesky et al., 1972) for the relative effectiveness of the drug. The results obtained by us showed the effectiveness of Triphala as a strong antiplaque agent. Probably the tannic acid (in Triphala), can be adsorbed well to the hydroxyapatite of the tooth or to the salivary mucins, alternately it can be bound to anionic groups on the surface of the bacterial cells, which resulted in protein denature and ultimately to the bacterial cell death (Bonesvoll et al., 1974). The increased oxidative stress has been postulated in the diabetic state (Boynes, 1991). Hence, the effective antioxidant property present in the extract may be useful in the treatment of diabetic patients having dental carries; whereas the sweetener present in the commercial pastes can delay the healing process or can harm the tooth.

The extract of Triphala can be employed as an effective agent to treat dental carries and to prevent the formation of dental plaques. Since the formulation is of herbal nature, it is renewable and can be made cheaper. 


\section{Acknowledgement}

The authors thank the Director, CAS in Botany, University of Madras for the laboratory facility.

\section{References}

1. Boynes JW (1991) Role of oxidative stress in development of complication in diabetics. Diabetes. 40, 405-411.

2. Bonesvoll $\mathrm{P}$, Lokker $\mathrm{P}$, Rolla $\mathrm{G}$ and Paus. (1974) Retention of chlorhexidine in the human oral cavity after mouthtrinses. Arch. Oral. Biol. 19, 209-212.

3. Chopra RN and Handa KL. (1958) In: Chopras's Indigenous Drugs in India $\left(2^{\text {nd }}\right.$ edited.), U.N. Dhurs and Sons, Clcutta, pp: 658-659.

4. Date BB and Kulkarni PH (1995) Assessment of Rasadanti in various oral disorders. Ayurveda Res. Pap. 2, 197-175.

5. Evans RT, Baker PJ, Coburn RA and Genco RJ (1977) Comparison of antiplaque agents using an in vitro assay reflecting oral conditions. J. Dental. Res. 56, 559-567.

6. Jagtap AG and Karkera SG (1999) Potential of the aqueous extract of Terminalia chebula as an anticaries agent. J. Ethnopharmacol. 68(13), 299-306.

7. Kau PC (1980) In: New Chinese Medicine Handbooks 1 (Ed. Wu B), Shing Wen Fang Publishing, China, pp: 288-291.

8. Lee HS, Nam HW and Kyaung HK (2005) Antioxidant activity of aqueous extract of $T$. chebula in vivo and in vitro. Biol. Pharmaceut. Bul. 28, 1639-1644.

9. Memory FE (1986) In: Proceedings of the International Seminar on Clinical Pharmacology in Devceloping Countries (Eds. Saxena RC \& Gupta TK), pp: 1-9.

10. Ooshima T, Minami T, Aono W, Tamura $Y$ and Hamada S (1994) Reduction of dental plaque formation in humans by Oolong tea extracts. Caries Res. 28, 146-149.

11. Pellegrini N, Roberta RE, Yang $M$ and Evans $C$ (1999) Screening of Dietary Carotenoids and Carotenoid-Rich Fruit Extracts for Antioxidant Activities applying 2, 2'Azinobis (3-ethylene benzothiazoline) 6-sulphonicacid and radical cation decolourisation assay. Methods Enzymol. 299, 379-390.

12. Sabu MC, Kuttan R (2002) Antidiabetic activity of medicinal plants and its relationship with their antioxidant property. J. Ethanopharmacol. $81,155-160$.

13. Schee A (1989) Modes of action of currently known chemical antiplaque agents other than chlorohexidine. J. Dental. Res. 68, 1609-1601.

14. Scherp HW (1971) Dental caries: Prospects for prevention. Science. 173, 1199-1205.
15. Turesky S, Glickman L and Sand Berg R (1972). In Vitro chemical inhibition of plaque formation, J. Periodontal. 43, 263-269. 